\title{
Financial structure effects on export intensity and diversification: the case of Portuguese industrial firms ${ }^{1}$
}

\author{
Luís Pacheco \\ Universidade Portucalense \\ Departament of Economics, Management and Computer Sciences, room 201 \\ Portucalense Institute for Legal Research - IJP \\ Research on Economics, Management and Information Technologies - REMIT \\ Rua Dr. António Bernardino de Almeida, 541-619, 4200-072 Porto - Portugal \\ luisp@upt.pt
}

\begin{abstract}
The objective of this paper is to empirically examine the relationship between a set of financial variables and export performance. Though many empirical papers studied the impact of financial structure on firms' performance its effect on firms' export performance has been less studied. The primary objective of our paper is to fill that gap, particularly for the case of Portugal, focusing on SMEs, where agency problems and lack of resources could impact more on export performance. Using a panel data methodology and considering a sample of 3.164 Portuguese manufacturing SMEs for the period 2011-2014 our results indicate that SMEs with less debt, higher profitability and of greater size tend to present higher export intensity and diversification. This exploratory paper gives a contribution to clarify which are the main financial determinants of an exportoriented firm, which is an important issue not only for managers but for all the stakeholders, particularly policy makers aiming to promote outward orientation of domestic firms.
\end{abstract}

Key-words: Financial structure, SMEs, Internationalization, Export intensity, Export diversity, Capital structure

\section{Introduction}

Internationalization represents a natural development for many firms but for others it constitutes a difficult barrier to surpass. International business literature has advanced a set of strategies and determinants of international diversification and trade (Buckley and Casson, 1976; Johanson and Vahlne, 1977; Dunning, 1980; Rugman, 1981; Hennart, 1982), highlighting the associated benefits and costs (Rugman, 1976; Zaheer, 1995). The most common forms of firms' internationalization, particularly for Small and Medium Enterprises (SMEs) are based on a low commitment perspective focusing on exporting, which offers greater flexibility and requires fewer resources than other ways of entering foreign markets (Leonidou, 2004; Ruzzier et al., 2006; Leonidou et al., 2007).

Until recently, the international economics literature and the corporate finance literature have evolved separately (Foley and Manova, 2015), being the present paper focused on the association of internationalization with capital structure and other firms' characteristics. Though many studies have advanced our understanding of firms' export determinants, there is a gap, at least in Portugal, of firm-level analysis linking capital structure and other financial characteristics with export performance, trying to unveil whether there exists a financial structure which is more convenient for SMEs willing to develop and improve their export performance. Due to the importance of exports to the growth path of the economy, several studies analyzed the export behavior from a macroeconomic perspective. However, studies focused on the firm-level export performance are very limited (Lileeva and Trefler, 2010; Bustos, 2010). This paper fills that gap using a

1 Published as: Pacheco, L. (2017), 'Financial structure effects on export intensity and diversification: the case of Portuguese industrial firms', Int. J. Globalisation and Small Business, Vol. 9, No. 4, pp.252-276. 
panel data methodology and considering a balanced sample of 3.164 Portuguese manufacturing SMEs for the period 2011-2014, with a total of 12.656 observations, concluding that debt structure, size, profitability and liquidity are relevant determinants of export diversity and intensity. Exports have been the primary engine of the recent, albeit incipient, Portuguese economic growth. Over the period 2011-2014, Portuguese GDP contracted 6,5\%, whereas exports grew at an annual rate of over 5\%, preventing an even worse economic performance. According to Banco de Portugal (2015), 21\% of SMEs can be considered exporting-firms, belonging $28 \%$ of them to the manufacturing sector, which represents almost $15 \%$ of Gross Value Added and $17 \%$ of total employment. The situation of Portuguese SMEs is particularly interesting since Portuguese firms present higher levels of debt financing compared to other European firms (IMF, 2015), which implies that Portuguese corporations' risk profiles may be different than the typically observed in other studies about the internationalization-financial structure link. The relevance of this line of research for policy is clear, since the identification of the firm-level factors that cause export activity would inform policies that are aimed at promoting outward orientation of domestic firms.

The rest of the paper is structured as follows. The next section presents a review of the literature on international diversification vs. capital structure and financial variables, ending with the justification for choosing Portuguese industrial SMEs. Section three presents the hypothesis to be tested, the data and the methodology to be used. The following section presents the empirical results and the final section discusses the results and presents some concluding remarks.

\section{Conceptual framework and hypotheses}

Due to globalization, a robust export performance, either measured in terms of scale or scope, is increasingly a critical factor for a firm general performance and survival. Different theoretic frameworks suggest several factors on the pace of internationalization. These can be classified as to whether stressing internal resource factors (such as market knowledge and the resource base of the firm) or external factors (such as market volume and the competitive environment) (Pedersen and Petersen, 1998; Sousa et al., 2008). For individual firms, entering the export market constitutes a high-risk decision that encompasses sunk costs, revenue volatility due to exchange rate movements, limited knowledge of external market conditions, local competition and cultural assimilation (Rocco, 1996). Different internal or firm-specific characteristics such as size, age, productivity and product diversification have been shown to be associated with SMEs internationalization (Graves and Thomas, 2004; Kontinen and Ojala, 2010).

"Financial resources" is generally treated as an internal resource and the emphasis on the internal accumulation of capital has led to the frequent use in empirical studies of firm size or age as a proxy for financial resources (Bonaccorsi, 1992; Ali and Camp, 1993). However, as argued below, empirical results for a relationship between size or age and foreign expansion are contradictory. Possibly, firm size (or age) is not a good indicator of the availability of free cash to invest in internationalization, since this depends on other factors. Specifically, financial structure, more than those variables could clearly influence the financial resources available to invest in internationalization. This paper falls within the literature of financial constraints and exports, dealing with the question of whether financial constraints hamper firms' ability to enter and succeed on foreign markets (Greenaway et al., 2007; Bellone et al., 2010; Minetti and Zhu, 2011; Askenazy et al., 2015). Although the direction of causality between firms' export performance and financial attributes is a matter of debate (Cantele and Campedelli, 2016), the literature agrees that exporters and nonexporters are different in terms of financial structure and liquidity. 
2.1 Export performance and firm capital structure

The lack of financial resources can constitute a serious obstacle to SMEs' international development as it prevents them from engaging into the necessary investments to improve their exporting activities. As supported by the Pecking Order theory (Myers and Majluf, 1984), firms generally prefer resort first to selffinancing, then debt and finally obtain financing from external partners. Albeit the impact of ownership structure on firms' performance has been well documented by the literature (e.g., Himmelberg et al., 1999; Joh, 2003), its effect on their export performance has been less studied and presents contradictory results (Zahra, 2003; Kontinen and Ojala, 2011; Sciascia et al., 2012; Majocchi and Strange, 2012).

Trying to understand the possible links between capital structure and internationalization, Weston and Brigham (1981) life-cycle model of the use of short-term debt captures a fundamental relationship between capital structure and growth in small firms. The authors argue that the combination of small size and rapid growth results in a finance gap for firms that do not have access to public capital markets. The cash required for growth outstrips internally generated funds, leading to slower growth or substantial short-term borrowing. This bias in the capital structure of small firms towards financing growth through internally generated funds and then through short-term debt is also reinforced by tax considerations, and a tendency among entrepreneurs to see external equity as expensive and dangerous in terms of interference and potential loss of control (Myers, 1984). So, cash demands of early and rapid internationalization could surpass internally generated funds. Further, the amount of short-term debt that can be raised could be constrained by limited collateral, the risk of foreign receivables and the negative impact on cash flow of debt repayment, creating a financing gap. Thus, internationalization funded from internal funds or short-term debt is most likely to be delayed or to proceed at a slower pace (McNaughton and Bell, 2004).

According to the free cash flow hypothesis (Jensen, 1986), there's an inverse relation between growth opportunities and debt ratios that predicts lower leverage for multinational corporations. In line with these arguments, Fatemi (1988), Burgman (1996) and Desai et al. (2008) find that multinational corporations have lower debt ratios. Fatemi (1988) show that multinational corporations have target leverage ratios significantly below those of their domestic counterparts due to risk considerations (e.g., exchange rate risk and political risk), a conclusion shared by Burgman (1996), who concludes that higher monitoring costs imply multinational firms lower debts levels. Desai et al. (2008) find that multinational firms with above-average exposures to politically risky countries have less domestic leverage than do other firms.

A similar conclusion, that firms' international activity leads to greater risk and agency costs, is reached by Lee and Kwok (1988), Chen et al. (1997) and Kwok and Reeb (2000). Lee and Kwok (1988) report that after controlling for size and industry related factors, multinational corporations have higher agency costs than domestic firms and that may explain why multinational corporations are less leveraged than domestic firms. Following Myers (1977), since multinational firms present higher growth opportunities, they should have higher agency costs of debt and, consequently, less leverage. Possibly, after a certain stage of internationalization, the relation could turn up positive, yielding a U-shaped relation (Saito and Hiramoto, 2010). Kwok and Reeb (2000) hypothesize that firms that export to riskier markets ("downstream") have lower debt capacity. For instance, firms that are more dependent and focused on outside EU markets face higher agency costs, so that will tend to present lower levels of leverage. On the contrary, when firms export to safer markets ("upstream", for instance, the EU market) its leverage increases due to the risk diversification. The greater geographic and institutional proximity with the EU markets implies lower agency costs for the firms focused on those markets, and so greater leverage. Finally, Doukas and Pantzalis (2003) provide evidence that suggests that multinational corporations face higher agency costs of debt than domestic firms, hence leading multinational corporations to seek less long-term debt financing than domestic firms. 
A general consensus of previous research is that international diversification is related to the capital structure of firms, although without agreeing on the direction of the relationship. Nevertheless, the bulk of empirical research finds evidence consistent with the proposition that international diversification is negatively related to leverage, at least for US firms. Most of the literature on this subject has been done in the US context. Apart from the US, the main previous studies analyzing the impact of international activity on leverage were based on French (Singh and Nejadmalayery, 2004; Askenazy et al., 2015; Bernini et al., 2015), Canadian (Mittoo and Zhang, 2008), German (Oesterle et al., 2013) and Brazilian (Novaes and Werlang, 1998; Saito and Hiramoto, 2010) multinational corporations. The fact that there are few studies applied to smaller and open countries and since the research tends to focus on large and listed corporations increases the importance of a similar study for Portuguese industrial SMEs. This paper hypothesizes that the financial structure of a SME must have an impact on its export performance as it constitutes a condition under which the firm will be able or not to make all the necessary investments to develop internationally and improve its export intensity and diversification.

\subsection{Export performance and other firm characteristics}

According to the resource-based view (RBV) of the firm (Barney, 1984; Wernerfelt, 1984), firms build sustained competitive advantages from the unique bundle of resources that they possess. So, a superior export performance could also be the result of the acquisition and exploitation of a set of resources by the firm. Dhanaraj and Beamish (2003) identify three sets of resources that encompass the resource domain of a firm, namely, managerial and organizational resources, entrepreneurial resources and technological resources. These quantitative and qualitative resources promote the firm's performance and, consequently, its export performance.

The RBV considers firm size as an indicator of managerial and financial resources available in the firm. Nevertheless, empirical findings in the existing literature that analyzed the relationship between firm size and export performance appear to be contradictory (Majocchi et al., 2005), since competitive advantages can be found in both large and small firms (Moen, 1999). Small firms could present highly specialized products with greater flexibility to enter and exit foreign markets (Bonaccorsi, 1992; Verwaal and Donkers, 2002). Nevertheless, it should be expected a positive relationship between firm size and internationalization due to the benefits of economies of scale that enable firms to overcome potential financial and human resource barriers arising from foreign activities (Calof, 1994; Manolova et al., 2002; Bausch and Krist, 2007). Larger firms posses a greater stock of resources, tend to be more diversified and have lower probability of bankruptcy (Ang, 1992; Cole, 2013). Also, due to lower information asymmetry larger firms have easier access to capital markets and pay lower interest rates, thus having greater possibilities to undertake internationalization processes. Smaller firms face limited resources, scale economies and a high risk perception in international activity, thus export a lower share of their sales (Navaretti et al., 2011).

Some authors argue that the inconsistency in results could be a consequence of the different indicators used to measure size or export performance (Nazar and Saleem, 2009). Additionally, Calof (1994) considers that differences in measurement, geography, firm size, and industry explain why results in similar studies have been inconsistent, making direct comparisons of results difficult. Finally, the relation could be non-linear. For instance, Sterlacchini (2001) analyzes the effect of firm size on the export performance of Italian firms, finding a positive relation, albeit negative for larger firms which progressively increase their foreign commitment, producing overseas and outsourcing their activities. Given the possibility of a curvilinear relationship, we test the square value of size, expecting a negative value for its coefficient. Also, since different sectors of activity could present different results, the relation between firm size and export intensity and diversification is 
examined across all industries to test whether the importance of economies of scale, product and technological specificities and transaction cost efficiencies vary considerably between industries.

The firm's asset structure could also constitute a factor influencing its export performance. Intangible expenses and assets, such as skilled workforce, patents and know-how, brands, strong customer relationships and unique organizational design and processes absorb a significant part of the firm's investment. Previous studies analyzed the impact of intangible assets on firms' performance (Henning et al., 2000), finding that the impact differs between sectors of activity (Villalonga, 2004). Focusing on internationalization, it is expected that the export competitive advantage of a firm is positively linked to its set of resources and capabilities, which includes intangible assets. This positive relationship was empirically analyzed by Braunerhjelm (1996), Rodríguez and Rodríguez (2005), Denicolai et al. (2015) and others. Nevertheless, knowledge assets are difficult to measure as such assets are heterogeneous in nature and difficult to define.

Concerning firm's financial performance, earlier studies on the correlation between export intensity and profitability were inconclusive (Gemunden, 1991). So, in this paper, it will be hypothesized that export intensity and diversity is a positive outcome of the firm's performance, measured by its profitability. That is, a good financial performance would motivate an increased degree of internationalization (Dhanaraj and Beamish, 2003).

A firm with high cash inflows should be more capable to mobilize the necessary resources for the internationalization process. This question derives from the idea that minimum levels of internal liquidity or access to external credit are necessary to finance the sunk costs of exporting, and it is largely inspired by theoretical models with financial frictions (Melitz, 2003; Manova, 2013; Manova et al., 2015; Chaney, 2016). Melitz (2003) takes into account those costs and proposes a model of international trade, in which entering the export market requires the payment of up-front costs that can be seen as an investment. Manova et al. (2015) find that financial frictions restrict firm decision into exporting and limit exporters' global sales, product scope, number of destinations and sales within each destination-product market. Research on this topic usually use credit-worthiness scores, balance sheet variables and credit rationing indicators to establish a relationship between liquidity constraints and exporting activities (Greenaway et al., 2007; Berman and Héricourt, 2010; Bellone et al., 2010; Minetti and Zhu, 2011; Wagner, 2014). Having a positive cash flow will enable SMEs to face additional costs and constraints linked to export activities, such as longer payment periods or entry costs, impossible to support without a healthy liquidity position (Bernard and Jensen, 1999). Consequently, the export intensity and diversification of the firm may be a consequence of its liquidity situation.

Finally, SMEs are subject to considerable levels of risk due to their dimension, dependence on export markets and need to constantly innovate and survive in a highly competitive market. Also, firms are exposed to business risk due to their economic environment and management skills. Risk reduces the firms' capability to finance and increases their costs (Myers, 1984; Low and Chen, 2004), but firms with higher levels of risk could regard internationalization as a way to diversify risk. In seminal papers Hirsch and Lev (1971) and Rugman (1976) show that the increase in foreign activities has a risk reduction effect on the firm, due to the traditional diversification effect (Stahrl and Sarkis, 1986; Shrader et al., 2000; Salomon and Shaver, 2005). The more the SME increases the number of its customers and targeted countries, the more it will be able to face a decline of one of its markets and compensate this decline with another source of revenues, improving its performance and increasing its survival probabilities (Bernard and Jensen, 1999). On the other hand, foreign activities increase a firm's systematic risk, exposing it to new risks that are not present in domestic markets (e.g., exchange rate risk, political risk), implying the monitoring and management of those risks, thus the gains from internationalization could be negative (Edmunds and Khoury, 1986). Kwok and Reeb (2000) elaborate this 
argument by noting that the risk reduction of international diversification depends on the firm's home and target conditions.

2.3 Summary: the research questions

Following the literature review made above we can now state the six main questions addressed in this paper:

i) What is the relation between firms' debt structure and export intensity and diversification?

ii) What is the relation between firms' size and export intensity and diversification?

iii) What is the relation between the firms' asset intangibility and export intensity and diversification?

iv) What is the relation between firms' profitability and export intensity and diversification?

v) What is the relation between the firms' liquidity and export intensity and diversification?

vi) What is the relation between firms' risk and export intensity and diversification?

Empirical efforts on factors influencing internationalization have shown that industry classification is a relevant factor, since industries present different financial structures, resource's demand and products with different levels of international marketability. So, this paper also tests for differences between manufacturing sectors.

\section{Hypothesis, data and methodology}

\subsection{Hypothesis}

This paper uses two different variables to measure "export performance", trying to characterize two fundamental dimensions: export diversification and export intensity. Concerning "export diversification", studies reported in the literature use different measures, so that a consensus is still lacking on the best or true measure of international diversification (Majocchi and Strange, 2012; Boehe and Jiménez, 2016). Some possible measures are the foreign sales percentage, the foreign tax ratio, the export sales growth or profitability, the number of countries in which the firm operates, entropy measures of the firm's geographical diversification and composite indexes. The use of a uni-dimensional measure such as the ratio of foreign sales to total sales does not take into account the geographical distribution of sales, i.e., whether or not they are geographically well balanced in major world markets (Boehe and Jiménez, 2016).

This paper uses a measure of entropy, which accounts for the dispersion or diversification of a firm's international sales. Considering the distribution of total sales in three main geographical areas (Portugal, the European Union and the rest of the world), we develop a measure of international diversification (INT) based on the Kim (1989) entropy index that has been extensively used in recent studies on international diversification (Majocchi and Strange, 2012).

$$
\text { Index of international diversification (INT) }=\sum_{j=1}^{3} x_{j} \ln \left(\frac{1}{x_{j}}\right)
$$

The subscript $\mathrm{j}$ defines one of the three markets and $\mathrm{x}_{\mathrm{j}}$ is the percentage of sales realized in market $\mathrm{j}$. The natural logarithm of the inverse of the sales realized in every market is the weight given to each geographical segment. The entropy measure will equal zero for firms that have all their sales concentrated in one region, and will reach a maximum value of 1,098 for firms with exactly the same share of sales in each of the three defined areas. Nevertheless, as stated by Majocchi and Strange (2012), such a measure also has some weaknesses: it is not expected that a firm's level of international sales to be evenly distributed between destiny areas, and an ideal measure of internationalization should not only measure the dispersion of foreign sales but also their level. 
Since it is important to measure export performance by different indicators in order to increase the reliability of the results, it will also be tested as dependent variables traditional measures of export intensity, namely, total exports as a percentage of total sales (EXP), the ratio between exports to EU countries and total sales (XIE) and the ratio between exports to countries outside EU and total sales (XOE) (Sousa et al., 2008). Notice that export diversification could depend on export intensity (Boehe and Jiménez, 2016), although that relation is not explored here.

Concerning the explanatory variables, the debt level of the firm is measured as total debt (Total liabilities / Total assets) and its subdivision in short-term and long-term debt (respectively, Current Liabilities / Total Assets and Non-current Liabilities / Total Assets). The debt ratios explain how the firm can finance its activity with its own resources and what degree of independence lies with external agents. In line with the papers reviewed above, we expect a negative relationship between total debt and internationalization, albeit a positive sign for short-term debt. Firm size is measured by the logarithm of total assets and it is expected a positive relationship with the internationalization indicators, being also tested the presence of a $\mathrm{U}$ or inverted$\mathrm{U}$ relation. Profitability is measured by ROA (return on assets) and asset intangibility by the ratio between current assets (less inventories) and total assets. It is expected a positive sign for these two variables, since more profitable firms and firms who made relatively more intangible expenses should present higher levels of internationalization due to the accumulation of resources. Notice that there is no standardized and consistent way of measuring a firm's intangible assets but the use of our measure is due to data availability. Intangibles recorded in the financial statements are not considered totally reliable and could go well beyond what appears in the financial statements (Wyatt, 2008). Regarding liquidity, this paper uses a measure of total liquidity (the ratio between current assets and current liabilities), since it measures the difference between the realization of revenues and the incurrence of expenses, and so how the firm can use the resulting liquidity to finance its internationalization. This measure of financial vulnerability constitutes and imperfect proxy, so measurement error can bias the results downward.

Finally, the variable risk will be proxied by the Solvency Ratio (SOR), which allows to assess how the firm finances itself and manages its ability to fulfill its non-current commitments, and to determine the dependence of the firm towards third parties. This ratio compares the levels of equity invested by the partners with the levels of debt capital applied by lenders. Obeying a principle of prudence, SOR should always have a value greater than or equal to one and shouldn't have values lower than 0,5 . The higher the SOR the lower is the risk and the firm sees no benefits to internationalize in order to diversify its activities and reduce risk. Thus, SOR should be negatively related to internationalization, albeit some differences could appear between the different measures of internationalization.

So, in order to answer our research questions, and according to the literature reviewed above, we will define the following hypotheses:

H1: Presence in export markets is negatively related to debt, ceteris paribus

H1.1: Presence in markets outside the EU is negatively related to debt, ceteris paribus

H1.2: Presence in the EU market is positively related to debt, ceteris paribus

H1.3: Presence in export markets is positively related to short-term debt and negatively related to longterm debt, ceteris paribus

H2: Presence in export markets is positively related to size, ceteris paribus

H2.1: Presence in export markets relation to size displays an inverted $U$-shape

H2.2: Presence in export markets relation to size varies between industries

H3: Presence in export markets is positively related to assets intangibility, ceteris paribus

H4: Presence in export markets is positively related to profitability, ceteris paribus 
H5: Presence in export markets is positively related to total liquidity, ceteris paribus

H6: Presence in export markets is negatively related to risk, ceteris paribus.

3.2 Data

In this paper we use a sample of Portuguese industrial SMEs. The dependent variables are the index of international diversification or a measure of export intensity and the independent variables represent the firm's internationalization determinant factors according to the previously stated hypothesis (Table 1).

Table 1 - Independent variables and expected signs (for EXP as dependent variable)

\begin{tabular}{l|lllc}
\hline HYP. & ACRONYM & INDEPENDENT VARIABLES & FORMULA & EXPECTED \\
\hline \multirow{2}{*}{ H1 } & TD & Total debt & Total liabilities / Total assets & SIGN \\
& STD & Short-term debt & Current Liabilities / Total Assets & - \\
& LTD & Long-term debt & Non-current Liabilities / Total Assets & - \\
H2 & SZ & Size & Logarithm of Total Assets & + \\
H3 & AI & Assets Intangibility & (Current Assets - inventories) / Total Assets & + \\
H4 & ROA & Return on Assets & EBIT / Total Assets & + \\
H5 & TL & Total Liquidity & Current Assets / Current Liabilities & + \\
H6 & SOR & Solvency Ratio & Equity / Total Liabilities & - \\
\hline
\end{tabular}

After the identification of the hypothesis to be tested as well as the dependent and independent variables, it is necessary to describe the data collection process for the sample characterization over which our empirical study will be made. Our objective is to analyze a sample of SMEs from the industrial sectors (CAEs 10 to 32), obtained from SABI, a financial database powered by Bureau van Dijk. Applying the criteria for SMEs definition and excluding firms with less than 10 employees, because micro firms tend to present gaps in terms of data and potential anomalous values, considering only firms with a 4 year period of complete data from 2011 to 2014 and excluding firms with debt ratios above $100 \%$ or negative or liabilities greater than assets, we obtained a balanced panel data of 3.164 SMEs. Table 2, presents a detailed description of our sample. The sample accounts for 168.017 employees, a turnover over 18.500 M€ and total assets of 20.000 M€ in 2014. The sample has two thirds of small firms (2.002) and one third of medium firms (1.162) and all relevant sectors are represented. In 2014, firms in the sample exported around 37,5\% of their sales, with almost two thirds of them presenting some exporting activity.

Table 2 allows to ascertain that exist significant differences between sectors in terms of exports, with some sectors exporting more than $50 \%$ of their sales, with others presenting values under $20 \%$. Also there are striking differences between sectors concerning the destination of exports. For instance, the wearing apparel sector has two thirds of its sales in the EU market, whereas other sectors already export a significant part of their sales to markets outside the EU (e.g., sectors 26 or 28). Differentiating between export-oriented firms or not, Table 2 considers that firms that make more than $10 \%$ of their sales abroad are export-oriented. Considering that threshold our sample has 1.171 domestic-oriented firms and 1.993 export-oriented firms (63\%). 
Table 2 - Distribution of the sample by industry classifications

\begin{tabular}{|c|c|c|c|c|c|c|c|c|}
\hline Industry Classification (CAE) & $\begin{array}{c}\text { Number } \\
\text { of } \\
\text { Firms } \\
\end{array}$ & $\begin{array}{l}\text { Exports } \\
\text { to EU (\%) }\end{array}$ & $\begin{array}{c}\text { Exports } \\
\text { to ex-EU } \\
(\%)\end{array}$ & $\begin{array}{c}\text { Small } \\
\text { Firms } \\
(\%) \\
\end{array}$ & $\begin{array}{c}\text { Export- } \\
\text {-oriented } \\
\text { firms (\%) } \\
\end{array}$ & $\begin{array}{c}\text { Total } \\
\text { Debt } \\
(\%) \\
\end{array}$ & $\begin{array}{l}\text { Aver. } \\
\text { nr. of } \\
\text { empl. }\end{array}$ & $\begin{array}{l}\text { Sales } \\
\text { (th€) }\end{array}$ \\
\hline Food products (10) & 427 & $10,1 \%$ & $3,4 \%$ & $64 \%$ & $33 \%$ & $61 \%$ & 53 & 3.771 .543 \\
\hline Beverages and tobacco $(11 / 12)$ & 104 & $14,6 \%$ & $13,9 \%$ & $86 \%$ & $59 \%$ & $58 \%$ & 30 & 555.924 \\
\hline Textiles (13) & 206 & $30,6 \%$ & $7,2 \%$ & $56 \%$ & $60 \%$ & $62 \%$ & 60 & 1.249 .341 \\
\hline Wearing apparel (14) & 245 & $66,1 \%$ & $4,8 \%$ & $49 \%$ & $89 \%$ & $66 \%$ & 68 & 1.286 .321 \\
\hline $\begin{array}{l}\text { Leather and related products } \\
\text { (15) }\end{array}$ & 205 & $54,9 \%$ & $5,6 \%$ & $43 \%$ & $78 \%$ & $66 \%$ & 68 & 1.102 .358 \\
\hline $\begin{array}{l}\text { Wood and of products of wood } \\
\text { and cork (16) }\end{array}$ & 180 & $24,5 \%$ & $10,5 \%$ & $76 \%$ & $65 \%$ & $62 \%$ & 41 & 930.171 \\
\hline Paper and paper products (17) & 75 & $15,5 \%$ & $3,4 \%$ & $67 \%$ & $51 \%$ & $65 \%$ & 50 & 577.535 \\
\hline $\begin{array}{l}\text { Printing and reproduction of } \\
\text { recorded media (18) }\end{array}$ & 86 & $6,5 \%$ & $4,3 \%$ & $71 \%$ & $34 \%$ & $61 \%$ & 43 & 296.137 \\
\hline $\begin{array}{l}\text { Refined petroleum, chemicals } \\
\text { and man-made fibers }(19 / 20)\end{array}$ & 110 & $12,8 \%$ & $5,7 \%$ & $81 \%$ & $38 \%$ & $58 \%$ & 37 & 954.781 \\
\hline Pharmaceutical products (21) & 20 & $12,4 \%$ & $9,3 \%$ & $20 \%$ & $55 \%$ & $55 \%$ & 107 & 264.877 \\
\hline $\begin{array}{l}\text { Rubber and plastic products } \\
(22)\end{array}$ & 188 & $22,9 \%$ & $4,7 \%$ & $64 \%$ & $61 \%$ & $59 \%$ & 54 & 1.319 .382 \\
\hline $\begin{array}{l}\text { Other non-metallic mineral } \\
\text { products (23) }\end{array}$ & 231 & $23,2 \%$ & $11,6 \%$ & $70 \%$ & $61 \%$ & $57 \%$ & 48 & 1.003.019 \\
\hline Basic metals (24) & 52 & $32,4 \%$ & $4,4 \%$ & $58 \%$ & $67 \%$ & $58 \%$ & 65 & 571.745 \\
\hline Fabricated metal products (25) & 497 & $27,3 \%$ & $10,1 \%$ & $67 \%$ & $70 \%$ & $60 \%$ & 48 & 1.918.188 \\
\hline $\begin{array}{l}\text { Computer, communication and } \\
\text { electronic equip. (26) }\end{array}$ & 26 & $27,8 \%$ & $15,1 \%$ & $50 \%$ & $73 \%$ & $48 \%$ & 74 & 159.871 \\
\hline Electrical equipment (27) & 66 & $25,9 \%$ & $10,8 \%$ & $62 \%$ & $73 \%$ & $57 \%$ & 53 & 427.529 \\
\hline Machinery and equipment (28) & 168 & $23,1 \%$ & $16,6 \%$ & $71 \%$ & $75 \%$ & $59 \%$ & 48 & 772.615 \\
\hline $\begin{array}{l}\text { Motor vehicles, trailers and } \\
\text { parts (29) }\end{array}$ & 66 & $37,9 \%$ & $11,8 \%$ & $47 \%$ & $85 \%$ & $60 \%$ & 67 & 462.281 \\
\hline Other transport equipment ( 30 ) & 22 & $48,0 \%$ & $10,5 \%$ & $45 \%$ & $77 \%$ & $54 \%$ & 72 & 127.977 \\
\hline Furniture (31) & 137 & $34,4 \%$ & $11,3 \%$ & $58 \%$ & $84 \%$ & $61 \%$ & 56 & 475.131 \\
\hline \multirow[t]{2}{*}{$\begin{array}{l}\text { Other manufacturing activities } \\
\text { (32) }\end{array}$} & 53 & $24,6 \%$ & $8,4 \%$ & $66 \%$ & $68 \%$ & $55 \%$ & 51 & 274.743 \\
\hline & 3.164 & $27,4 \%$ & $8,7 \%$ & $63 \%$ & $63 \%$ & & & 18.501 .469 \\
\hline
\end{tabular}

Note: Small firms are firms with less than 50 employees and export-oriented firms are firms which export more than $10 \%$ of its total sales. Sectors $11 / 12$ and 19/20 are aggregated since the sample only comprises a very small number of firms in sectors 12 and 19.

Before estimating the different models we present some descriptive statistics of the variables. As can be seen in Table 3, in recent years, the indebtedness levels decreased slightly and firms present an improvement in ROA, liquidity and solvency ratios. In the considered period, firms increased slightly their exports for EU countries and significantly for markets outside the EU.

Table 3 also presents the correlation matrix of the variables. According to Gujarati and Porter (2008), when the correlation coefficients are above $50 \%$, the problem of collinearity becomes significant. Observing the correlation coefficients between the independent variables only in two circumstances the correlation coefficient is above $50 \%$, therefore the problem of collinearity between explanatory variables will not be particularly relevant. 


\begin{tabular}{|c|c|c|c|c|c|c|c|c|c|}
\hline & 2014 & 2011 & s.d. & TD & ROA & AI & SZ & TL & SOR \\
\hline INT & 0,43 & 0,39 & 0,34 & & & & & & \\
\hline EXP (\%) & 37,5 & 33,6 & 35,9 & & & & & & \\
\hline of which & & & & & & & & & \\
\hline XOE (\%) & 9,1 & 6,7 & 15,8 & & & & & & \\
\hline XIE (\%) & 28,4 & 26,9 & 32,6 & & & & & & \\
\hline TD & 0,61 & 0,64 & 0,19 & 1 & $\begin{array}{c}-0,199 \\
(* * *)\end{array}$ & $\begin{array}{c}-0,030 \\
(* * *)\end{array}$ & $\begin{array}{c}-0,162 \\
(* * *)\end{array}$ & $\begin{array}{c}-0,440 \\
(* *)\end{array}$ & $\begin{array}{c}-0,607 \\
(* * *)\end{array}$ \\
\hline \multicolumn{10}{|l|}{ of which } \\
\hline STD & 0,41 & 0,44 & 0,18 & & $\begin{array}{c}-0,071 \\
(* * *)\end{array}$ & $\begin{array}{c}0,211 \\
(* * *)\end{array}$ & $\begin{array}{c}-0,198 \\
\left({ }^{* * *}\right)\end{array}$ & $\begin{array}{c}-0,472 \\
(* * *)\end{array}$ & $\begin{array}{c}-0,410 \\
(* * *)\end{array}$ \\
\hline LTD & 0,19 & 0,20 & 0,14 & & $\begin{array}{c}-0,169 \\
(* * *)\end{array}$ & $\begin{array}{c}-0,299 \\
(* * *)\end{array}$ & $\begin{array}{l}0,035 \\
(* * *)\end{array}$ & $\begin{array}{c}0,017 \\
\left(^{*}\right)\end{array}$ & $\begin{array}{c}-0,276 \\
(* * *)\end{array}$ \\
\hline ROA & 5,45 & 4,17 & 7,00 & & 1 & $\begin{array}{l}0,239 \\
\left({ }^{* * *}\right)\end{array}$ & $\begin{array}{c}-0,060 \\
(* * *)\end{array}$ & $\begin{array}{c}0,054 \\
(* * *)\end{array}$ & $\begin{array}{c}0,071 \\
(* * *)\end{array}$ \\
\hline AI & 0,46 & 0,46 & 0,20 & & & 1 & $\begin{array}{c}-0,245 \\
(* * *)\end{array}$ & $\begin{array}{c}0,163 \\
\left({ }^{* *}\right)\end{array}$ & $\begin{array}{c}0,020 \\
(* *)\end{array}$ \\
\hline SZ & 8,28 & 8,16 & 1,00 & & & & 1 & $\begin{array}{c}0,041 \\
(* * *)\end{array}$ & $\begin{array}{c}0,115 \\
(* * *)\end{array}$ \\
\hline TL & 1,97 & 1,84 & 1,98 & & & & & 1 & $\begin{array}{c}0,635 \\
(* * *)\end{array}$ \\
\hline SOR & 1,00 & 0,83 & 1,68 & & & & & & 1 \\
\hline
\end{tabular}

Note: s.d. is the standard deviation. ${ }^{*} \mathrm{p}<0,10$; $^{* *} \mathrm{p}<0,05$; $^{* * *} \mathrm{p}<0,01$.

3.3 Methodology

In order to attain our research objective we apply two different econometric techniques. Firstly, a panel data methodology, which presents several advantages, namely better effects' detection and measurement, minimization in sample bias and control of individual heterogeneity (Gujarati and Porter, 2008). Panel data can be estimated trough three different regression models: Pooled Ordinary Least Squares (POLS), Fixed Effects Model (FEM) and Random Effects Model (REM). Applying the Wald, Breusch-Pagan and Hausman tests we will choose the most appropriate regression technique. First, comparing between POLS and FEM, the Wald test states the null hypothesis of the constant terms being all equal. Under the null hypothesis, the efficient estimator is the POLS model, indicating the non existence of a specific effect for each one of the firms. After, the Breusch-Pagan test compares between POLS and REM, where the rejection of the null hypothesis indicates that REM is more appropriate. Finally, the Hausman test compares REM with FEM, where under the null hypothesis the efficient estimator is the REM. If we reject the null hypothesis, the FEM is more appropriate, since the REM would yield biased results. Secondly, since the two dependent variables are left-censored (obviously, there are no values below zero for INT and EXP, XIE or XOE are defined between zero and one), we adopt a Tobit methodology (Gujarati and Porter, 2008). Tobit regressions are nonlinear therefore the coefficients should be interpreted with care and do not measure the real causal effect on the dependent variable. This effect is correctly measured only by the marginal effect however the coefficients maintain the significance and sign of the marginal effects, allowing the test of our hypothesis. In the two methodologies we run the dependent variables (INT, EXP, XIE or XOE) on the variables TD (also divided in STD and LTD), SZ, AI, ROA, TL and SOR.

\section{Empirical results}

4.1 Results for the complete sample 
Comparing the results obtained for Pooled OLS (POLS), Fixed Effects Model (FEM) and Random Effects Model (REM), the Wald and Breusch-Pagan tests indicate the rejection of the Pooled OLS model and the Hausman test rejects the random effects model, indicating that the fixed effects model is more efficient. The upper part of Table 4 presents the fixed effects regression results for the alternative dependent variables INT (international diversification), EXP (total exports to sales ratio), XIE (EU exports to sales ratio) and XOE (outside EU exports to sales ratio). The explanatory power of the FEM model is given by the $\mathrm{R}^{2}$ and the $\mathrm{F}$ and Durbin-Watson statistics. The lower part of Table 4 presents the regression results for the same dependent variables but with a Tobit specification, with its significance assessed by reference to the Wald $\chi^{2}$ statistic and the log-likelyhood ratio. The fixed-effects model results present a good goodness of fit with a $\mathrm{R}^{2}$ around $90 \%$. The Tobit regressions show comforting results for the overall indexes of goodness of fit ( $\chi^{2}$ and log-likelyhood ratio), suggesting that the overall specification of the model is good. We now analyze the results at the light of the different hypothesis.

Table 4 - Regression results: Fixed effects model and Tobit model

\begin{tabular}{|c|c|c|c|c|c|c|c|c|c|c|c|}
\hline & Coef. & Sig. & & Coef. & Sig. & & Coef. & Sig. & & Coef. & Sig. \\
\hline \multicolumn{12}{|c|}{ Fixed-effects model } \\
\hline INT & & & EXP & & & XIE & & & XOE & & \\
\hline $\mathrm{C}$ & ,127 (,088) & & $\mathrm{C}$ &, $024(, 080)$ & & $\mathrm{C}$ &, $058(, 072)$ & & $\mathrm{C}$ &,$- 082(, 040)$ & $* *$ \\
\hline TD &,$- 067(, 033)$ & $* *$ & $\mathrm{TD}$ &,$- 065(, 028)$ & $* *$ & TD &,$- 063(, 025)$ & $* *$ & $\mathrm{TD}$ &,$- 003(, 015)$ & \\
\hline ROA &,$- 019(, 038)$ & & ROA & ,073 (,033) & $* *$ & ROA & ,021 (,029) & & ROA &, $052(, 020)$ & $* * *$ \\
\hline AI &,$- 027(, 024)$ & & $\mathrm{AI}$ &, $035(, 021)$ & & $\mathrm{AI}$ &, $001(, 020)$ & & AI &, $029(, 011)$ & $* * *$ \\
\hline SZ &, $042(, 011)$ & $* * *$ & SZ &, $049(, 010)$ & $* * *$ & SZ &, $031(, 010)$ & $* * *$ & SZ &, $018(, 005)$ & $* * *$ \\
\hline $\mathrm{TL}$ &,$- 003(, 001)$ & $*$ & $\mathrm{TL}$ &,$- 002(, 002)$ & & $\mathrm{TL}$ &,$- 000(, 001)$ & & $\mathrm{TL}$ &,$- 001(, 002)$ & \\
\hline SOR &, $002(, 003)$ & & SOR &, $002(, 003)$ & & SOR &,$- 000(, 003)$ & & SOR &, $002(, 001)$ & \\
\hline $\mathrm{R}^{2}$ & ,87 & & & ,93 & & & ,93 & & & ,85 & \\
\hline $\mathrm{F}$ & 21,57 & $* * *$ & & 41,61 & $* * *$ & & 42,58 & $* * *$ & & 16,75 & $* * *$ \\
\hline DW & 1,57 & & & 1,50 & & & 1,52 & & & 1,57 & \\
\hline INT & & & EXP & & & XIE & & & XOE & & \\
\hline C & ,122 (,089) & & C & ,026 (,080) & & $\mathrm{C}$ & ,055 (,073) & & C &,$- 081(, 040)$ & $* *$ \\
\hline STD &,$- 053(, 034)$ & & STD &,$- 061(, 029)$ & $* *$ & STD &,$- 057(, 027)$ & $* *$ & STD &,$- 004(, 016)$ & \\
\hline LTD &,$- 089(, 038)$ & $* *$ & LTD &,$- 074(, 031)$ & $* *$ & LTD &,$- 073(, 027)$ & $* * *$ & LTD &,$- 001(, 019)$ & \\
\hline ROA &,$- 020(, 038)$ & & ROA & ,073 (,033) & $* *$ & ROA & ,021 (,029) & & ROA &, $052(, 020)$ & $* * *$ \\
\hline AI &,$- 034(, 024)$ & & $\mathrm{AI}$ &, $033(, 022)$ & & $\mathrm{AI}$ &, $003(, 021)$ & & AI &, $030(, 012)$ & $* *$ \\
\hline SZ &, $043(, 011)$ & $* * *$ & SZ &, $050(, 010)$ & $* * *$ & SZ & ,032 (,001) & $* * *$ & SZ &, $018(, 005)$ & $* * *$ \\
\hline $\mathrm{TL}$ &,$- 002(, 001)$ & & $\mathrm{TL}$ &,$- 001(, 002)$ & & $\mathrm{TL}$ &, $000(, 001)$ & & $\mathrm{TL}$ &,$- 001(, 002)$ & \\
\hline SOR &, $002(, 003)$ & & SOR &, $001(, 003)$ & & SOR &,$- 000(, 003)$ & & SOR &, $002(, 001)$ & \\
\hline $\mathrm{R}^{2}$ & ,88 & & & ,93 & & & ,93 & & & ,85 & \\
\hline $\mathrm{F}$ & 21,57 & $* * *$ & & 41,60 & $* * *$ & & 42,56 & $* * *$ & & 16,74 & $* * *$ \\
\hline DW & 1,57 & & & 1,50 & & & 1,53 & & & 1,57 & \\
\hline \multicolumn{12}{|l|}{ Tobit model } \\
\hline INT & & & EXP & & & XIE & & & XOE & & \\
\hline $\mathrm{C}$ &,$- 105(, 032)$ & $* * *$ & $\mathrm{C}$ &,$- 123(, 035)$ & $* * *$ & $\mathrm{C}$ &,$- 019(, 032)$ & & $\mathrm{C}$ &,$- 104(, 015)$ & $* * *$ \\
\hline $\mathrm{TD}$ &,$- 085(, 020)$ & $* * *$ & $\mathrm{TD}$ &, $058(, 020)$ & $* * *$ & $\mathrm{TD}$ & ,089 (,018) & $* * *$ & $\mathrm{TD}$ &,$- 032(, 009)$ & $* * *$ \\
\hline ROA & $105(, 043)$ & $* *$ & ROA &, $540(, 053)$ & $* * *$ & ROA & ,466 (,050) & $* * *$ & ROA & ,073 (,022) & $* * *$ \\
\hline AI &,$- 128(, 016)$ & $* * *$ & $\mathrm{AI}$ &,$- 030(, 017)$ & $*$ & $\mathrm{AI}$ &,$- 025(, 016)$ & & AI &,$- 005(, 008)$ & \\
\hline SZ & ,077 (,003) & $* * *$ & SZ &, $054(, 003)$ & $* * *$ & SZ &, $029(, 003)$ & $* * *$ & SZ &, $025(, 001)$ & $* * *$ \\
\hline $\mathrm{TL}$ &, $004(, 003)$ & & $\mathrm{TL}$ &, $002(, 003)$ & & $\mathrm{TL}$ &, $000(, 003)$ & & $\mathrm{TL}$ &, $002(, 001)$ & \\
\hline SOR &,$- 015(, 003)$ & $* * *$ & SOR &,$- 009(, 002)$ & $* * *$ & SOR &,$- 005(, 002)$ & $* *$ & SOR &,$- 004(, 001)$ & $* * *$ \\
\hline $\operatorname{LR} \chi^{2}(\mathrm{df}=2)$ & 7884,41 & $* * *$ & & 11291,30 & $* * *$ & & 11913,60 & $* * *$ & & 11200,50 & $* * *$ \\
\hline LLR & $-3749,48$ & & & $-4878,24$ & & & $-3750,88$ & & & 5592,18 & \\
\hline INT & & & EXP & & & XIE & & & XOE & & \\
\hline $\mathrm{C}$ &,$- 106(, 032)$ & $* * *$ & $\mathrm{C}$ &,$- 124(, 035)$ & $* * *$ & $\mathrm{C}$ &,$- 019(, 032)$ & $* * *$ & $\mathrm{C}$ &,$- 104(, 015)$ & $* * *$ \\
\hline STD &,$- 063(, 022)$ & $* * *$ & STD &, $168(, 024)$ & $* * *$ & STD & $198(, 022)$ & $* * *$ & STD &,$- 031(, 010)$ & $* * *$ \\
\hline LTD &,$- 124(, 026)$ & $* * *$ & LTD &,$- 135(, 027)$ & $* * *$ & LTD &,$- 104(, 024)$ & $* * *$ & LTD &,$- 032(, 012)$ & $* * *$ \\
\hline ROA &, $106(, 043)$ & $* *$ & ROA &, $543(, 052)$ & $* * *$ & $\mathrm{ROA}$ & $468(, 050)$ & $* * *$ & ROA &, $073(, 022)$ & $* * *$ \\
\hline AI &,$- 143(, 017)$ & $* * *$ & $\mathrm{AI}$ &,$- 106(, 019)$ & $* * *$ & $\mathrm{AI}$ &,$- 101(, 017)$ & $* * *$ & AI &,$- 005(, 008)$ & \\
\hline SZ & $077(, 003)$ & $* * *$ & SZ &, $055(, 003)$ & $* * *$ & SZ &, $030(, 003)$ & $* * *$ & SZ & $025(, 001)$ & $* * *$ \\
\hline $\mathrm{TL}$ &, $006(, 003)$ & $*$ & $\mathrm{TL}$ &, $012(, 003)$ & $* * *$ & $\mathrm{TL}$ &, $010(, 003)$ & $* * *$ & $\mathrm{TL}$ &, $002(, 001)$ & \\
\hline SOR &,$- 017(, 003)$ & $* * *$ & SOR &,$- 016(, 003)$ & $* * *$ & SOR &,$- 012(, 002)$ & $* * *$ & SOR &,$- 004(, 001)$ & $* * *$ \\
\hline $\operatorname{LR} \chi^{2}(\mathrm{df}=2)$ & 7770,88 & $* * *$ & & 10781,00 & $* * *$ & & 11564,60 & $* * *$ & & 11201,50 & $* * *$ \\
\hline
\end{tabular}


$\begin{array}{llcc}\text { LLR }-3746,76 & -4819,46 & -3680,88 & 5592,14\end{array}$ Note: Standard-deviations presented in brackets. DW = Durbin Watson. ${ }^{*} \mathrm{p}<0,10 ;{ }^{* *} \mathrm{p}<0,05 ;{ }^{* * *} \mathrm{p}<0,01$.

\section{Hypothesis 1 - Debt}

The leverage variable tends to present a negative and statistically significant coefficient, meaning that firms employing more debt in their capital structure have on average a lower degree of export diversification and intensity. Also, when leverage is divided in short-term debt and long-term debt, only in the Tobit specification appears a difference in signs, with short-term debt presenting the expected positive sign for the variables EXP and XIE. This difference thus indicates that firms' tend to resort to short-term debt in order to internationalize, thus confirming hypothesis 1.3. Also in the lower panel we can see that firms that are more focused on the outside-EU markets present lower levels of debt, possibly because face higher agency costs when entering higher risk markets and, on the contrary, firms focused on the EU market display higher debt levels, thus also confirming hypothesis 1.1 and 1.2. So, globally, the results tend to confirm hypothesis 1 , so that less leveraged firms seem to be more export-oriented or higher levels of debt turn the internationalization process more difficult, which is a result also found by other authors (e.g., Minetti and Zhu, 2011; Majocchi and Strange, 2012; Bernini et al., 2015). This result is in line with the predictions of agency theory, since a high level of leverage imposes a fixed financial commitment on the firm, reducing the free cash flows available to management and the possibilities to internationalize. Also, we are dealing with SMEs, mostly of them of a familiar nature, so the negative relation could be explained by the family's concerns with increased levels of financial risk and fears of losing control (Zahra, 2005).

\section{Hypothesis 2 - Size}

Larger firms display higher internationalization levels, strongly confirming hypothesis 2 and the resourcebased view. The variable size is shown to exert a positive and significant impact in all measures of export activity, demonstrating that larger firms can afford the high costs of exporting. This result that confirms the positive relationship between resources and internationalization was also found in several analyzes of the relationship between size and export intensity and diversification (e.g., Filatotchev et al., 2008; Sousa et al., 2008; Majocchi and Strange, 2012). Considering size a proxy for age, this result also suggests that exporting firms follow an internationalization process consistent with the Uppsala model (Johanson and Vahlne, 1977). Albeit not presented, when testing for non-linear effects of size on internationalization, the squared value of size is never statistically significant and negatively affects the quality of the specification, thus not confirming hypothesis 2.1 .

\section{Hypothesis 3 - Assets Intangibility}

Regarding the lower panel, the observed relationship between AI and INT or EXP is statistically significant though with a negative sign. These results do not confirm hypothesis 3, contradict some previous research (Braunerhjelm, 1996; Rodríguez and Rodríguez, 2005; Denicolai et al., 2014) and do not confirm the resourcebased view approach. On the contrary, it seems that accumulating a relatively large amount of fixed and tangible assets encourage export activities, a relationship possibly also captured by the size variable. Nevertheless, our results could be biased by the broad assets' intangibility measure used, with narrower measures of intangible or knowledge assets possibly yielding different results. Denicolai et al. (2014) argue that knowledge assets should have a positive, but diminishing impact, upon firm international performance, so that the relation is non-linear. A high proportion of intangible assets (e.g., patents or licenses) may imbalance 
the resources and capabilities base and thus impair the firm's ability to export, providing incentives to concentrate on domestic sales.

\section{Hypothesis 4 - Profitability}

In our study, ROA presents the expected positive sign relative to the different dependent variables, thus confirming hypothesis 4 . So firms with higher profitability are firms with a greater possibility to retain earnings and thus obtain internally the necessary resources to finance an internationalization process. The export orientation seems to be an outcome of the firm's performance, but some caution is necessary here due to a possible inverse causality of this relationship (Dhanaraj and Beamish, 2003).

\section{Hypothesis 5 - Total Liquidity}

Our results do not suggest that liquidity problems generally hamper firm's export performance, either in terms of export intensity either in terms of export diversity. Nevertheless, the variable TL is significant in the Tobit specification, presenting a positive sign for INT, EXP and XIE, suggesting that firms with higher levels of liquidity seem to be better able to undertake internationalization processes. This positive effect of liquidity, confirming hypothesis 5, was also found by Bernard and Jensen (1999), Bellone et al. (2010) and Manova et al. (2015), among others.

\section{Hypothesis 6 - Risk}

For risk to be positively associated with INT or EXP it is expected that SOR has a negative sign. According to the results, it can be concluded that risk is positively related with internationalization, suggesting that exporting activity acts as a risk diversification strategy. Concerning the dependent variable INT in the Tobit model, we can see that the significant negative coefficient implies that the lesser is the level of risk the lower is the internationalization diversification. That is, firms with lower levels of risk, and so without the need to diversify sources of revenues, tend to diversify less their exports.

\subsection{Results for the different sectors of activity}

Some prior studies show industry to be a significant determinant of internationalization. So, we now repeat the analysis distinguishing between sectors of activity but, due to space availability, Table 5 presents only the results estimated trough a Tobit Model with EXP as the dependent variable.

Analyzing Table 5, and considering all the significant results that display the expected sign (in bold), we confirm that profitability and size are the main determinants of internationalization in almost all manufacturing sectors, with a secondary role played by liquidity and debt, with these last two variables being more significant in the group of sectors located on the upper part of the table.

Concerning the variable size, the results do not confirm hypothesis 2.2 since we found a positive and significant relationship in almost all sectors, with the exception of sectors 21, 23, 24 and 27. Possibly, the higher technological content of those sectors explains the unimportance of the benefits gained with the exploration of economies of scale provided by a greater firm size. As for the possibility of a non-linear relation between size and export intensity, albeit the results are not presented, we found seven sectors with a significant U-shape relation between internationalization and size (sectors 10, 11/12, 13, 16, 25, 27 and 31) and only in one sector it is observed an inverted U-shape. Thus, being size always a determinant factor, in some sectors it seems to be important to attain a sufficiently high scale in order to better expand internationalization. 
Table 5 - Tobit Model for the different manufacturing sectors, with EXP as the dependent variable:

\begin{tabular}{|c|c|c|c|c|c|c|c|c|c|c|c|}
\hline & CAE 10 & $11 / 12$ & 13 & 14 & 15 & 16 & 17 & 18 & $19 / 20$ & 21 & 22 \\
\hline \multirow[t]{2}{*}{$\mathbf{C}$} &,$- 350 * * *$ &,- 018 &,$- 500 * * *$ &,- 204 &,$- 742^{* * *}$ &,$- 471^{* * *}$ &,$- 648^{* * *}$ &,$- 874^{* * *}$ &,- 159 &,$- 946^{*}$ &,$- 882^{* * *}$ \\
\hline & $(, 063)$ & $(, 194)$ & $(, 151)$ & $(, 157)$ & $(, 223)$ & $(, 143)$ & $(, 225)$ & $(, 133)$ & $(, 124)$ & $(, 496)$ & $(, 114)$ \\
\hline \multirow[t]{2}{*}{ STD } &, 096 &,- 014 &,- 152 & ,139 &, $676^{* * *}$ &,- 143 &, $444^{* *}$ &, $461^{* * *}$ & ,239*** & $1,546^{* * *}$ & , 165 \\
\hline & $(, 059)$ & $(, 136)$ & $(, 099)$ & $(, 141)$ & $(, 194)$ & $(, 090)$ & (,197) & $(, 140)$ & $(, 088)$ & (,551) & $(, 101)$ \\
\hline \multirow[t]{2}{*}{ LTD } &, 017 &,$- 277 * * *$ &, 026 &,- 095 &, 216 &,$- 293^{* * *}$ & ,279 & ,099 &,- 093 &, $878^{* *}$ &, $313^{* * *}$ \\
\hline & $(, 062)$ & $(, 098)$ & $(, 104)$ & $(, 157)$ & $(, 239)$ & $(, 091)$ & $(, 219)$ & $(, 116)$ & $(, 121)$ & $(, 344)$ & $(, 112)$ \\
\hline \multirow[t]{2}{*}{ ROA } &, $267 * * *$ &,- 246 &, 065 &, $\mathbf{5 1 8}^{* * *}$ &, 094 &, $960 * * *$ &, 415 &, $569 * * *$ &, $290 * *$ & ,183 &, $573^{* * *}$ \\
\hline & $(, 094)$ & $(, 246)$ & $(, 212)$ & $(, 154)$ & $(, 190)$ & $(, 246)$ & $(, 261)$ & $(, 169)$ & $(, 147)$ & $(, 539)$ & $(, 203)$ \\
\hline \multirow[t]{2}{*}{ AI } &,$- 224 * * *$ &,$- 200 * *$ &,$- 140 *$ & ,112* &,- 072 &,- 005 &,$- 332^{* * *}$ & ,080 &,$- 440 * * *$ &,$- 468^{* *}$ &,- 061 \\
\hline & $(, 029)$ & $(, 096)$ & $(, 078)$ & $(, 068)$ & $(, 092)$ & $(, 066)$ & $(, 110)$ & $(, 094)$ & $(, 082)$ & $(, 207)$ & $(, 059)$ \\
\hline \multirow[t]{2}{*}{$\mathbf{S Z}$} &, $061^{* * *}$ & ,041** & $114 * * *$ & $104^{* * *}$ &, $094^{* * *}$ &, $117^{* * *}$ &, $074 * * *$ &, $084 * * *$ &, $048 * * *$ &, 039 &, $121^{* * *}$ \\
\hline & $(, 005)$ & $(, 019)$ & $(, 014)$ & $(, 013)$ & ,016 & $(, 013)$ & $(, 013)$ & $(, 011)$ & $(, 012)$ & $(, 041)$ & $(, 010)$ \\
\hline \multirow[t]{2}{*}{ TL } &, $016^{* * *}$ &, $047^{* *}$ & ,042* &,- 013 &, $154^{* * *}$ &,$- 022^{* * *}$ &, 009 & ,023* & $0,48^{* *}$ &, $042^{* *}$ &,- 000 \\
\hline & $(, 002)$ & $(, 020)$ & ,022 & $(, 015)$ & $(, 039)$ & $(, 005)$ & $(, 011)$ & $(, 012)$ & $(, 019)$ & $(, 019)$ & $(, 006)$ \\
\hline \multirow[t]{2}{*}{ SOR } &,- 005 &,$- 025^{* * *}$ &,$- 034^{* * *}$ &, 008 &, 024 &,- 010 & ,138** &, 006 &,$- 034 * *$ &, $122^{*}$ &, 022 \\
\hline & $(, 010)$ & $(, 007)$ & $(, 012)$ & $(, 032)$ & $(, 058)$ & $(, 006)$ & $(, 067)$ & $(, 023)$ & $(, 013)$ & $(, 068)$ & $(, 016)$ \\
\hline $\operatorname{LR} \chi^{2}$ & 1480,4 & 151,6 & 602,6 & 599,7 & 695,7 & 340,9 & 193,1 & 251,2 & 355,1 & 51,2 & 417,2 \\
\hline \multirow[t]{2}{*}{ LLR } & 144,8 & $-56,5$ & $-285,4$ & $-332,1$ & $-369,6$ & $-189,9$ & 56,4 & 122,3 & $-24,2$ & $-4,3$ & $-54,8$ \\
\hline & 23 & 24 & 25 & 26 & 27 & 28 & 29 & 30 & 31 & 32 & \\
\hline \multirow[t]{2}{*}{ C } & ,781*** &, $806^{* * *}$ &,$- 437 * * *$ &,- 482 &,- 076 &,$- 660 * * *$ &,- 148 & $-1,098^{* * *}$ &,- 021 &,$- 649 *$ & \\
\hline & $(, 142)$ & $(, 236)$ & $(, 084)$ & $(, 358)$ & $(, 291)$ & $(, 134)$ & $(, 231)$ & $(, 419)$ & $(, 198)$ & $(, 220)$ & \\
\hline \multirow[t]{2}{*}{ STD } &, 035 &,- 049 &,- 085 & ,182 &, $776 * * *$ &, 062 &, 115 & ,572* &,- 073 & ,208 & \\
\hline & $(, 108)$ & $(, 162)$ & $(, 066)$ & $(, 300)$ & $(, 264)$ & $(, 114)$ & $(, 194)$ & $(, 299)$ & $(, 165)$ & $(, 188)$ & \\
\hline \multirow[t]{2}{*}{ LTD } &,- 028 &,$- 442 * *$ &,$- 256 * * *$ & -266 &,- 116 & ,179 &, 070 &, $927^{* * *}$ &,$- 373 * *$ &,- 249 & \\
\hline & $(, 116)$ & $(, 177)$ & $(, 069)$ & $(, 367)$ & $(, 245)$ & $(, 127)$ & $(, 241)$ & $(, 227)$ & $(, 154)$ & $(, 216)$ & \\
\hline \multirow[t]{2}{*}{ ROA } & $1,031^{* * *}$ &, 000 & ,246* &,$- 889 * * *$ & ,161 &, $736^{* * *}$ &, 126 &,$- 755^{*}$ & ,810*** &, $751^{* * *}$ & \\
\hline & $(, 192)$ & $(, 208)$ & $(, 131)$ & $(, 322)$ & $(, 220)$ & $(, 172)$ & $(, 342)$ & $(, 404)$ & $(, 197)$ & $(, 286)$ & \\
\hline \multirow[t]{2}{*}{ AI } &,$- 308 * * *$ &,$- 728 * * *$ &,- 042 &,- 038 &,$- 355^{* * *}$ &, 009 &,$- 283^{* *}$ &,$- 558^{* *}$ &,- 051 & , 149 & \\
\hline & $(, 067)$ & $(, 116)$ & $(, 047)$ & $(, 182)$ & $(, 102)$ & $(, 068)$ & $(, 124)$ & $(, 279)$ & $(, 096)$ & $(, 164)$ & \\
\hline \multirow[t]{2}{*}{ SZ } &,$- 038^{* * *}$ &,- 006 &, $119 * * *$ &, $098^{* * *}$ &, 027 &, $116^{* * *}$ &, $075^{* * *}$ & ,158*** &, $075^{* * *}$ &, $102 * * *$ & \\
\hline & $(, 013)$ & $(, 022)$ & $(, 008)$ & $(, 027)$ & $(, 020)$ & $(, 011)$ & $(, 020)$ & $(, 365)$ & $(, 018)$ & $(, 024)$ & \\
\hline \multirow[t]{2}{*}{ TL } &,$- 007 * * *$ &,- 007 &,$- 028^{* *}$ &, 041 &, 019 &,- 008 & ,065* &, 064 &, 030 &, 048 & \\
\hline & $(, 002)$ & $(, 032)$ & $(, 012)$ & $(, 037)$ & $(, 023)$ & $(, 013)$ & $(, 038)$ & $(, 053)$ & $(, 021)$ & $(, 031)$ & \\
\hline \multirow[t]{2}{*}{ SOR } &,- 008 &, $053^{*}$ &,- 007 &, 025 &, 065 &, 024 &,- 063 &, $047^{* *}$ &,$- 083 * * *$ &,$- 058 *$ & \\
\hline & $(, 012)$ & $(, 029)$ & $(, 009)$ & $(, 032)$ & $(, 046)$ & $(, 023)$ & $(, 048)$ & $(, 019)$ & $(, 028)$ & $(, 031)$ & \\
\hline $\operatorname{LR} \chi^{2}$ & 776,9 & 57,8 & 1077,0 & 26,6 & 180,9 & 312,1 & 87,8 & 2,9 (NS) & 368,2 & 154,4 & \\
\hline LLR & $-355,3$ & $-35,7$ & $-551,0$ & $-22,2$ & $-54,6$ & $-130,0$ & $-64,5$ & $-15,2$ & $-166,9$ & $-56,1$ & \\
\hline
\end{tabular}

In sum, concerning the determinants of internationalization here considered, there seems to exist no significant major differences between sectors of activity. Nevertheless, the majority of the small differences found could be related to industry specific factors, which justifies further research. We return to this issue in the last section.

Finally, and before the concluding section, Table 6 presents a comparison between the expected and observed relationships, where we can validate the different hypotheses that were tested in this empirical study.

Table 6 - Expected and Observed Relations (Dependent variable = EXP)

\begin{tabular}{|c|c|c|c|c|}
\hline \multicolumn{2}{|c|}{$\begin{array}{l}\text { EXPLANATORY } \\
\text { VARIABLES }\end{array}$} & $\begin{array}{c}\text { EXPECTED RELATION } \\
--\end{array}$ & $\begin{array}{c}\text { OBSERVED RELATION } \\
-\end{array}$ & $\begin{array}{c}\text { HYPOTHESIS VALIDATED? } \\
\text { YES }\end{array}$ \\
\hline H1 & $\begin{array}{l}\text { TD } \\
\text { STD } \\
\text { LTD }\end{array}$ & $\begin{array}{l}- \\
+ \\
-\end{array}$ & $\begin{array}{l}- \\
+ \\
-\end{array}$ & $\begin{array}{l}\text { YES } \\
\text { YES } \\
\text { YES }\end{array}$ \\
\hline $\mathrm{H} 2$ & SZ & + & + & YES \\
\hline
\end{tabular}




\begin{tabular}{cllll} 
H3 & AI & + & - & NO \\
H4 & ROA & + & + & YES \\
H5 & TL & + & + & YES \\
H6 & SOR & - & - & YES \\
\hline Note: “+" - Positive Relation; “-" - Negative Relation.
\end{tabular}

\section{Discussion and conclusions}

This exploratory paper presents an original theoretical analysis of the multidimensional concept of export performance, adopting a financial point of view, contrary to most studies related to this topic that adopt a marketing or strategic approach. We constructed a balanced sample of 3.164 industrial SMEs for a period of 4 years, between 2011 and 2014, with a total of 12.656 observations. The hypotheses tested in this paper have been rarely tested in other country contexts and time periods, being this paper to our knowledge the first one to test them for Portuguese industrial firms.

Regarding the six main questions addressed in this paper, we can answer that: i) industrial SMEs tend to present a negative relationship between firms' debt structure and export intensity and diversification; ii) firms' size and export intensity and diversification are strongly positively related; iii) it was not found a significant positive relationship between firms' asset intangibility and their export intensity and diversification; iv) firms' profitability presents a positive relationship with export intensity and diversification; v) firms' liquidity tends to present a positive relationship with export intensity and diversification and finally, vi) the greater the firms' risk the greater their export intensity and diversification.

The relevance of these results for policy is clear, since the identification of some firm-level factors that cause export activity would inform policies that are aimed at promoting outward orientation of domestic firms. For instance, since firm size has a significant impact on export intensity and diversification, policy measures should focus on the scale of production to boost international sales, thus promoting joint-ventures, mergers and the acquisition of economies of scale. This seems to be particularly relevant in those sectors where it is found a significant U-shaped relationship. Also, the provision of access to short-term finance could enhance firms' capabilities to undertake internationalization processes, an issue that also deserves the attention of policymakers.

Some limitations of this study should be mentioned: i) in the first place, firms' export activity is affected by many variables that were not considered (e.g., managerial labor and product markets, government incentives to internationalize, political and economic factors or even the personality of shareholders and managers), meaning that the results should be treated with caution; ii) secondly, a factor that limits the generalization of the results is that the study focuses only on the Portuguese industrial SMEs; iii) finally, the measures of internationalization used in the literature differ widely, leaving us with the question whether our results are dependent on the measures used. The linkages between export diversification and intensity are not explored. For instance, the degree of export intensity could affect the cost-benefit relationship of geographic export diversification. Also, future research could use a measure that combines the international scale and scope of the firm in order to reflect the true nature of the internationalization process.

Export performance certainly depends on the financial structure of the SMEs but it also depends on other determinants (internal or not) which will surely have an impact on the financial structure itself. So, further research should, inter alia, (i) introduce qualitative variables, for instance, consider problems in terms of access to internationalization incentives and consider internal factors such as the corporate governance structure, product positioning, marketing and brand management and the firm's specific resources, namely, the impact of the stock of social capital and networks on internationalization; (ii) further analyze the presence 
of differences between sectors, for instance, taking into account sectors' differences in terms of economies of scale, $R \& D$ and technological investment needs or the nature and quality of exported goods; iii) finally, there is scope to further develop empirical researches grounded on the resource-based view. For instance, here it was not researched the enterprise commitment of the firm to internationalize or issues related to the specific technological resources or intensity in different sectors. Also, the results create an incentive to further explore how different intangible assets impact upon firm export performance.

In summary, the results of this paper allow to conclude that the degree of internationalization is influenced by firm-specific characteristics, such as leverage, size and liquidity, supporting the idea that firms possessing a healthier financial structure present higher degrees of export diversification and intensity. We hope this paper stimulates future research on this less studied topic of financial structure determinants of internationalization.

\section{REFERENCES}

Ali, A. and Camp, R. (1993) "The relevance of firm size and international business experience to market entry strategies", Journal of Global Marketing, Vol. 6, No. 4, pp. 91-112.

Ang, J. (1992) “On the theory of finance for privately held firms”, Journal of Small Business Finance, Vol. 1, No. 3, pp. 185-203.

Askenazy, P., Caldera, A., Gaulier, G. and Irac, D. (2011) "Financial constraints and foreign market entries or exits: Firm-level evidence from France”, Review of World Economics, Vol. 151, No. 2, pp. 231-253.

Banco de Portugal (2015) Análise das Empresas do Setor Exportador em Portugal, Estudos da Central de Balanços, No. 22, June.

Barney, J. (1991) “Firm resources and sustained competitive advantage”, Journal of Management, Vol. 17, No. 1, pp. 99-120.

Bausch, A. and Krist, M. (2007) "The effect of context-related moderators on the internationalizationperformance relationship: Evidence from meta-analysis", Management International Review, Vol. 47, No. 3, pp. 319-347.

Bellone, F., Musso, P., Nesta, L. and Schiavo, S. (2010) "Financial constraints and firm export behavior", The World Economy, Vol. 33, No. 3, pp. 347-373.

Berman, N. and Héricourt, J. (2010) "Financial factors and the margins of trade: Evidence from cross-country firm-level data", Journal of Development Economics, Vol. 93, No. 2, pp. 206-217.

Bernard, A. and Jensen, J. (1999) “Exceptional export performance: cause, effect, or both?", Journal of International Economics, Vol. 47, No. 1, pp. 1-25.

Bernini, M., Guillou, S. and Bellone, F. (2015) "Financial leverage and export quality: Evidence from France", Journal of Banking and Finance, Vol. 59, pp. 280-296.

Boehe, D. and Jiménez, A. (2016) "How does the geographic export-diversification-performance relationship vary at different levels of export intensity?, International Business Review, Vol. 25, No. 6, pp. 1262-1272.

Bonaccorsi, A. (1992) "On the relationship between firm size and export intensity", Journal of International Business Studies, Vol. 23, pp. 605-635.

Braunerhjelm, P. (1996) “The relation between firm-specific intangibles and exports”, Economics Letters, Vol. 53, No. 2, pp. 213-219.

Buckley, P. and Casson, M. (1976) The Future of the Multinational Enterprise, Basingstoke, Macmillan.

Burgman, T. (1996) “An empirical examination of multinational corporate capital structure”, Journal of International Business Studies, Vol. 27, No. 3, pp. 553-570.

Bustos, P. (2011) "Trade liberalization, exports, and technology upgrading: Evidence on the impact of MERCOSUR on Argentinian firms", American Economic Review, Vol. 101, No. 1, pp. 304-40. 
Calof, J. (1994) "The relationship between firm size and export behavior revisited", Journal of International Business Studies, Vol. 25, No. 2, pp. 367-387.

Cantele, S. and Campedelli, B. (2016) “Internationalisation and performance of SMEs: exploring the moderating effects of intangible assets and capital intensity, International Journal of Business and Globalisation, Vol. 17, No. 2, pp. 205-223.

Chaney, T. (2016) "Liquidity constrained exporters", Journal of Economic, Dynamics and Control, Vol. 72, pp. 141-154.

Chen, C., Cheng, C., He, J. and Kim, J. (1997) “An investigation of the relationship between international activities and capital structure”, Journal of International Business Studies, Vol. 28, No. 3, pp. 563-577.

Cole, R. (2013) "What do we know about the capital structure of privately held US firms? Evidence from the surveys of small business finance", Financial Management, Vol. 42, No. 4, pp. 777-813.

Denicolai, S., Zuchella, A. and Strange, R. (2014) "Knowledge assets and firm international performance", International Business Review, Vol. 23, pp. 55-62.

Desai, M., Foley, C. and Hines, J. (2008) “Capital structure with risky foreign investment”, Journal of Financial Economics, Vol. 88, No. 3, pp. 534-553.

Dhanaraj, C. and Beamish, P. (2003) "A resource-based approach to the study of export performance", Journal of Small Business Management, Vol. 41, No. 3, pp. 242-261.

Doukas, J. and Pantzalis, C. (2003) “Geographic diversification and agency costs of debt of multinational firms", Journal of Corporate Finance, Vol. 9, No. 1, pp. 59-92.

Dunning, J. (1980) “Towards an eclectic theory of international production: Some empirical tests", Journal of International Business Studies, Vol. 11, No. 1, pp. 9-31.

Edmunds, S. and Khoury, S. (1986) "Exports: A necessary ingredient in the growth of small business firms", Journal of Small Business Management, Vol. 24, pp. 54-65.

Fatemi, A. (1988) "The effect of international diversification on corporate financing policy", Journal of Business Research, Vol. 16, No. 1, pp. 17-30.

Filatotchev, I., Stephan, J. and Jindra, B. (2008) "Ownership structure, strategic controls and exporting of foreign-invested firms in transition economies", Journal of International Business Studies, Vol. 39, No. 7, pp. 1133-1148.

Foley, C. and Manova, K. (2015) "International trade, multinational activity, and corporate finance", Annual Review of Economics, Vol. 7, pp. 119-46.

Gemunden, H.-G. (1991) "Success factors on export marketing: A meta-analytic critique of the empirical studies", in S. Paliwoda (Ed.), New Perspectives on International Marketing, Routledge, London, pp. 33-62.

Graves, C. and Thomas, J. (2004) "Internationalisation of the family business: A longitudinal perspective”, International Journal of Globalisation and Small Business, Vol. 1, No. 1, pp. 7-27.

Greenaway, D.; Guariglia, A. and Kneller, R. (2007) "Financial factors and exporting decisions", Journal of International Economics, Vol. 73, No. 2, pp. 377-395.

Gujarati, D. and Porter, D. (2008) Basic Econometrics, $5^{\text {th }}$ edition, Irwin, McGraw-Hill.

Hennart, J. (1982) A Theory of Multinational Enterprise, Ann Arbor, University of Michigan.

Henning, S., Lewis, B. and Shaw, W. (2000) "Valuation of the components of purchased goodwill”, Journal of Accounting Research, Vol. 38, No. 2, pp. 375-386.

Himmelberg, C., Hubbard, R. and Palia, D. (1999) "Understanding the determinants of managerial ownership and the link between ownership and performance", Journal of Financial Economics, Vol. 53, No. 3, pp. 353-384.

Hirsch, S. and Lev, B. (1971) "Sales stabilization through export diversification", The Review of Economics and Statistics, Vol. 53, No. 3, pp. 270-277. 
IMF (2015) Global Financial Stability Report, World Economic and Financial Surveys, International Monetary Fund, April.

Jensen, M. (1986) "Agency costs of free cash flow, corporate finance and takeover", American Economic Review, Vol. 76, pp. 323-329.

Joh, S. (2003) "Corporate governance and firm profitability: evidence from Korea before the economic crisis", Journal of Financial Economics, Vol. 68, No. 2, pp. 287-322.

Johanson, J. and Vahlne, J.-E. (1977) "The internationalization process of the firm: A model of knowledge development and increasing foreign market commitments", Journal of International Business Studies, Vol. 8, No. 1, pp. 23-32.

Kim, W. (1989) “Developing a global diversification measure”, Management Science, Vol. 35, No. 3, pp. 376-383. Kontinen, T. and Ojala, A. (2010) "The internationalization of family businesses: A review of extant research", Journal of Family Business Strategy, Vol. 1, No. 2, pp. 97-107.

Kontinen, T. and Ojala, A. (2011) "International opportunity recognition among small and medium-sized family firms", Journal of Small Business Management, Vol. 49, No. 3, pp. 490-514.

Kwok, C. and Reeb, D. (2000) "Internationalization and firm risk: An upstream-downstream hypothesis", Journal of International Business Studies, Vol. 31, No. 4, pp. 611-629.

Lee, K. and Kwok, C. (1988) "Multinational corporations vs. domestic corporations: international environmental factors and determinants of capital structure", Journal of International Business Studies, Vol. 19, No. 2, pp. 195-217.

Leonidou, L. (2004) "An analysis of the barriers hindering small business export development”, Journal of Small Business Management, Vol. 42, pp. 229-302.

Leonidou, L., Katsikeas, C., Palihawadana, D. and Spyropoulu, S. (2007) “An analytical review of the factors stimulating smaller firms to export", International Marketing Review, Vol. 24, pp. 735-770.

Lileeva, A. and Trefler, D. (2010) "Improved access to foreign markets raises plant-level productivity. . for some plants", The Quarterly Journal of Economics, Vol. 125, No. 3, pp. 1051-1099.

Low, P. and Chen, K. (2004) "Diversification and capital structure: some international evidence”, Review of Quantitative Finance and Accounting, Vol. 23, pp. 55-71.

Majocchi, A. and Strange, R. (2012) "International diversification: the impact of ownership structure, the market for corporate control and board independence", Management International Review, Vol. 52, pp. 879900.

Majocchi, A.; Bacchiocchi, E. and Mayrhofer, U. (2005) "Firm size, business experience and export intensity in SMEs: A longitudinal approach to complex relationships", International Business Review, Vol. 14, pp. 719-738.

Manolova, T., Brush, C., Edelman, L. and Greene, P. (2002) “Internationalization of small firms: Personal factors revisited”, International Small Business Journal, Vol. 20, No. 1, pp. 9-31.

Manova, K. (2013) “Credit constraints, heterogeneous firms, and international trade", The Review of Economic Studies, Vol. 80, No. 2, pp. 711-744.

Manova, K., Wei, S.-J. And Zhang, Z. (2015) "Firm exports and multinational activity under credit constraints", Review of Economics and Statistics, Vol. 97, No. 3, pp. 574-588.

McNaughton, R. and Bell, J. (2004) "Capital structure and the pace of SME internationalization", in Hamid Etemad (Ed.), International Entrepreneurship in Small and Medium Size Enterprises: Orientation, Environment and Strategy, Cheltenham, Edward-Elgar, chap. 3.

Melitz, M. (2003) "The impact of trade on intra-industry reallocations and aggregate industry productivity", Econometrica, Vol. 71, No. 6, pp. 1695-1725. 
Minetti, R. and Zhu, S. (2011) “Credit constraints and firm export: Microeconomic evidence from Italy", Journal of International Economics, Vol. 83, No. 2, pp. 109-125.

Mittoo, U. and Zhang, Z. (2008) "The capital structure of multinational corporations: Canadian versus US evidence", Journal of Corporate Finance, Vol. 14, No. 5, pp. 706-720.

Moen, 0. (1999) "The relationship between firm size, competitive advantage and export performance revisited", International Small Business Journal, Vol. 18, pp. 53-72.

Myers, S. (1984) “The capital structure puzzle”, Journal of Finance, Vol. 39, No. 3, pp. 575-597.

Myers, S. and Majluf, N. (1984) "Corporate financing and investment decisions when firms have information that investors do not have", Journal of Financial Economics, Vol. 13, No. 2, pp. 187-221.

Navaretti, G., Bugamelli, M., Schivardi, F., Altomonte, C., Horgos, D. and Maggioni, D. (2011) “The global operations of European firms: the second EFIGE policy report”. Bruegel Blueprint 12, July.

Nazar, M. and Saleem, H. (2009) "Firm-level determinants of export performance", International Business and Economics Research Journal, Vol. 8, No. 2, pp. 105-112.

Novaes, W. and Werlang, S. (1998) "Capital structure choice of foreign subsidiaries: evidence from multinationals in Brazil", Ensaios Econômicos EPGE 340.

Oesterle, M., Richta, H. and Fisch, J. (2013) "The influence of ownership structure on internationalization", International Business Review, Vol. 22, No. 1, pp. 187-201.

Pedersen, T. and Petersen, B. (1998) "Explaining gradually increasing resource commitment to a foreign market”, International Business Review, Vol. 7 No. 5, pp. 483-501.

Rocco, V. (1996) “Going global: A CEO’s perspective”, Journal of Management in Engineering, Vol. 12, No. 2, pp. 21-24.

Rodríguez, J. and Rodríguez, R. (2005) "Technology and export behaviour: A resource-based view approach", International Business Review, Vol. 14, No. 5, pp. 539-557.

Rugman, A. (1976) "Risk reduction by international diversification”, Journal of International Business Studies, Vol. 7, No. 2, pp. 75-80.

Rugman, A. (1981) Inside the Multinationals: The economics of internal markets, New York, Columbia University Press.

Ruzzier, M., Hisrich, R. and Antoncic, B. (2006) "SME internationalization research: Past, present, and future", Journal of Small Business and Enterprise Development, Vol. 13, No. 4, pp. 476-497.

Saito, R. and Hiramoto, E. (2010) "Foreign activity effects and capital structure: Brazilian evidence", Academia Revista Latinoamericana de Administración, Vol. 45, pp. 59-75.

Salomon, R. and Shaver, J. (2005) "Export and domestic sales: Their interrelationship and determinants", Strategic Management Journal, Vol. 26, No. 9, pp. 855-871.

Sciascia, S., Mazzola, P., Astrachan, J. and Pieper, T. (2012) "The role of family ownership in international entrepreneurship: Exploring nonlinear effects", Small Business Economics, Vol. 38, No. 1, pp. 15-31.

Shrader, R., Oviatt, B. and McDougall, P. (2000) "How new ventures exploit trade-offs among international risk factors: Lessons for the accelerated internationalization of the 21st century", Academy of Management Journal, Vol. 43, No. 6, pp. 1227-1247.

Singh, M. and Nejadmalayeri, A. (2004) "Internationalization, capital structure, and cost of capital: evidence from French corporations", Journal of Multinational Financial Management, Vol. 14, No. 2, pp. 153-69.

Sousa, C., Martínez-López, F. and Coelho, F. (2008) "The determinants of export performance: A review of the research in the literature between 1998 and 2005”, International Journal of Management Reviews, Vol. 10, No. 4, pp. 343-374. 
Stahrl, E. and Sarkis, J. (1986) "Exports: a necessary ingredient in the growth of small business firms", Journal of Small Business Management, Vol. 24, No. 4, pp. 54-65.

Sterlacchini, A. (2001) "The determinants of export performance: A firm-level study of Italian manufacturing", Weltwirtschaftliches Archiv, Vol. 137, No. 3, pp. 450-472.

Verwaal, E. and Donkers, B. (2002) "Firm size and export intensity: Solving an empirical puzzle", Journal of International Business Studies, Vol. 33, pp. 603-613.

Villalonga, B. (2004) “Intangible resources, Tobin's q, and sustainability of performance differences”, Journal of Economic Behavior \& Organization, Vol. 54, No. 2, pp. 205-230.

Wagner, J. (1995) “Exports, firm size, and firm dynamics”, Small Business Economics, Vol. 7, No. 1, pp. 29-39.

Wagner, J. (2014) “Credit constraints and exports: evidence for German manufacturing enterprises”, Applied Economics, Vol. 46, No. 3, pp. 294-302.

Wernerfelt, B. (1984) “A resource-based view of the firm”, Strategic Management Journal, Vol. 5, No. 2, pp. 171-180.

Weston, J. and Brigham, E. (1981) Managerial Finance, Hinsdale, Dryden Press.

Wyatt, A. (2008) "What financial and non-financial information on intangibles is value relevant? A review of the evidence, Accounting and Business Research, Vol. 38, No. 3, pp. 217-256.

Zaheer, S. (1995) "Overcoming the liability of foreignness", Academy of Management Journal, Vol. 38, No. 2, pp. 341-363.

Zahra, S. (2003) "International expansion of US manufacturing family businesses: The effect of ownership and involvement", Journal of Business Venturing, Vol. 18, No. 4, pp. 495-512.

Zahra, S. (2005) “Entrepreneurial risk taking in family firms”, Family Business Review, Vol. 18, No. 1, pp. 23-40. 